\title{
85. Palaeomagnetic Studies on Tertiary and Cretaceous Rocks in Japan
}

\author{
By Takesi Nagata, Syun-iti Akimoto, Yoshio Shimizu, \\ Kazuo KoBAYASHI \\ Geophysical Institute, University of Tokyo \\ and Hisashi Kuno \\ Geological Institute, University of Tokyo \\ (Comm. by S. Nakamura, M.J.A., July 13, 1959)
}

Palaeomagnetic studies on Quaternary igneous rocks in Japan have almost been completed, the results showing that, in large time-scale, the north or south axis-pole of the geomagnetic field was situated within 30 degrees from the present geographic pole during the Quaternary period. Fairly comprehensive studies on rocks of the North-Izu and Hakone volcanic region, made by the authors, ${ }^{1)}$ show that, during the whole Quaternary period, the geomagnetic dipole has been fluctuating around an axis, the north pole of which wandered from $72^{\circ} \mathrm{N}, 86^{\circ} \mathrm{E}$ to $81^{\circ} \mathrm{N}, 32^{\circ} \mathrm{W}$, and that the direction of polarization of the dipole was reversed at a certain time in the earliest Quaternary. This result is consistent with those of studies on European rocks. Of the process of reversal of the geomagnetic dipole, a detailed study was carried out by examining a series of the Tertiary and Quaternary igneous rocks in Nagano prefecture (K. Momose). ${ }^{2}$ According to the results obtained by the authors and Momose, it is likely that the whole process of reversal took place in a very short interval of time, compared with that of quasi-steadily fluctuating of the geomagnetic dipole around an axis, which is thought to have nearly coincided with the earth's geographic axis.

As a sequence of the previous studies on Quaternary rocks, palaeomagnetic research of Tertiary igneous rocks and Cretaceous sedimentary rocks in Japan has been continued by the authors, and the results are compared with those obtained from rocks in other parts of the world.

For the Tertiary, rock-samples were collected at ten sites in five localities, several hundred kilometers apart from one another in Honsyû, Japan - near Sendai, Sidara basin (Aiti prefecture), Tanna basin (Sizuoka prefecture), valley of the river Huzi, and near Toyama. For the Cretaceous, red shales of the Inkstone series were collected at three localities in Yamaguti prefecture. Stratigraphic succession of the geologic units at each locality is shown in Table I, where it is to be noted that the rock-samples collected cover almost the whole of the Neogene and the Middle or Lower Cretaceous. At each site five to 





Table II. General results of the palaeomagnetic measurements for Tertiary and Cretaceous rocks

\begin{tabular}{|c|c|c|c|c|c|}
\hline Locality & $\begin{array}{l}\text { Number of } \\
\text { samples }\end{array}$ & Declination & Inclination & $\begin{array}{l}\text { Circle of } \\
\text { confidence } \\
(5 \%)\end{array}$ & Intensity range \\
\hline $\begin{array}{c}\text { Near Sendai } \\
\text { Mitaki } 1 \\
, " \quad 2 \\
\text { Moniwa }\end{array}$ & $\begin{array}{l}5 \\
5 \\
6\end{array}$ & 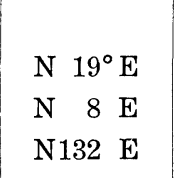 & $\begin{array}{l}+46^{\circ} \\
+58 \\
-63\end{array}$ & $\begin{array}{r}7^{\circ} \\
7 \\
12\end{array}$ & $\begin{array}{r}\frac{\text { e.m.u. }}{\mathrm{gr} .} \\
0.74-3.08 \times 10^{-3} \\
3.34-6.00 \times 10^{-4} \\
1.74-5.45 \times 10^{-4}\end{array}$ \\
\hline $\begin{array}{l}\text { Sidara basin } \\
\text { Ôkuwa } \\
\text { Tengudana } \\
\text { Syôziiwa }\end{array}$ & $\begin{array}{r}7 \\
7 \\
12\end{array}$ & $\begin{array}{l}\text { N155 } \\
\text { N161 } \\
\text { N } 19 \\
\text { E }\end{array}$ & $\begin{array}{l}-71 \\
-57 \\
+57\end{array}$ & $\begin{array}{r}6 \\
4 \\
11\end{array}$ & $\begin{array}{l}2.40-8.33 \times 10^{-4} \\
2.75-12.69 \times 10^{-4} \\
0.90-3.01 \times 10^{-4}\end{array}$ \\
\hline $\begin{array}{l}\text { Tanna basin } \\
\text { East of } \\
\text { Tanna } \\
\text { Simo-tanna }\end{array}$ & $\begin{array}{l}5 \\
7\end{array}$ & $\begin{array}{cll}\mathrm{N} & 8 & \mathrm{E} \\
& 0\end{array}$ & $\begin{array}{l}+46 \\
+40\end{array}$ & $\begin{array}{l}7 \\
7\end{array}$ & $\begin{array}{l}1.02-1.61 \times 10^{-3} \\
1.22-2.63 \times 10^{-3} \\
\end{array}$ \\
\hline $\begin{array}{l}\text { Valley of the } \\
\text { river Huzi } \\
\text { Minobu } \\
\text { Tukimi-basi }\end{array}$ & $\begin{array}{l}6 \\
7\end{array}$ & $\begin{array}{lll}\mathrm{N} & 49 & \mathrm{E} \\
\mathrm{N} & 36 & \mathrm{E}\end{array}$ & $\begin{array}{l}+47 \\
+50\end{array}$ & $\begin{array}{r}17 \\
8\end{array}$ & $\begin{array}{l}2.80-9.32 \times 10^{-4} \\
0.93-2.57 \times 10^{-3}\end{array}$ \\
\hline $\begin{array}{l}\text { Near Toyama } \\
\text { Iwaine }\end{array}$ & 7 & $\mathrm{~N} 23 \mathrm{E}$ & +8 & 15 & $0.40-4.33 \times 10^{-4}$ \\
\hline $\begin{array}{c}\text { Yamaguti } \\
\text { pref. } \\
\text { Ôkôti } \\
\text { Imoziya } \\
\text { Ohuku }\end{array}$ & $\begin{array}{l}24 \\
15 \\
23\end{array}$ & $\begin{array}{lll}\mathrm{N} & 81 & \mathrm{E} \\
\mathrm{N} & 50 & \mathrm{E} \\
\mathrm{N} & 43 & \mathrm{E}\end{array}$ & $\begin{array}{l}+54 \\
+46 \\
+46\end{array}$ & $\begin{array}{l}4 \\
4 \\
7\end{array}$ & $\begin{array}{l}0.29-0.97 \times 10^{-5} \\
0.95-1.79 \times 10^{-5} \\
0.84-1.78 \times 10^{-5}\end{array}$ \\
\hline
\end{tabular}

twelve samples were usually taken over a distance of several meters. Mean direction and intensity of natural remanent magnetization of rock-samples for each site, measured with an astatic magnetometer, are listed in Table II, where radius of five percent circle of confidence according to Fisher $^{3}$ is also given. As is seen in this table, three groups of the Miocene rock-samples have reverse magnetic polarity.

Throughout the whole course of the above-mentioned studies, unstably magnetized rock-samples were rejected, a criterion thereof, recently established by the authors' research group (Akimoto and Kushiro), ${ }^{4}$ being that rocks containing titanomaghemite ( $r$ state of $x \mathrm{TiFeO}_{3} \cdot(1-x) \quad \mathrm{Fe}_{2} \mathrm{O}_{3}$ of inverse spinel type crystal structure with lattice defect), which is usually produced by oxidization of titanomagnetite $\left(x \mathrm{TiFe}_{2} \mathrm{O}_{4} \cdot(1-x) \mathrm{Fe}_{3} \mathrm{O}_{4}\right)$, are generally very unstable in their magnetization. 
Table III. Summary of the palaeomagnetic research on Tertiary and Cretaceous rocks in Japan

\begin{tabular}{|c|c|c|c|c|c|c|c|c|}
\hline & Geological age & $\begin{array}{c}\text { Mean } \\
\text { declination }\end{array}$ & $\begin{array}{c}\text { Mean } \\
\text { inclination }\end{array}$ & $\alpha$ & $\begin{array}{r}\text { Pole } \\
\text { (Latituc }\end{array}$ & $\begin{array}{l}\text { osition } \\
\text { (Longi- } \\
\text { tude) }\end{array}$ & $\delta p^{*} \delta m^{*}$ & $\begin{array}{l}\text { Number } \\
\text { of rock- } \\
\text { samples }\end{array}$ \\
\hline & $\begin{array}{c}\text { Upper Pliocene } \\
\text { Tanna basin }\end{array}$ & $\mathrm{N} \quad 3^{\circ} \mathrm{E}$ & $+42^{\circ}$ & $2^{\circ}$ & $79^{\circ} \mathrm{N}$ & $57^{\circ} \mathrm{W}$ & $2^{\circ} \quad 3^{\circ}$ & 12 \\
\hline & $\begin{array}{l}\text { Lower Pliocene } \\
\text { Mitaki }\end{array}$ & $\mathrm{N} 14^{\circ} \mathrm{E}$ & $+52^{\circ}$ & $4^{\circ}$ & $77^{\circ} \mathrm{N}$ & $109^{\circ} \mathrm{W}$ & $4^{\circ} \quad 6^{\circ}$ & 10 \\
\hline  & $\begin{array}{l}\text { Upper or Middle } \\
\text { Miocene } \\
\text { Minobu, } \\
\text { Sidara basin }\end{array}$ & $\mathrm{N} 27^{\circ} \mathrm{E}$ & $+59^{\circ}$ & $3^{\circ}$ & $68^{\circ} \mathrm{N}$ & $152^{\circ} \mathrm{W}$ & $4^{\circ} \quad 5^{\circ}$ & 32 \\
\hline I & $\begin{array}{l}\text { Lower Miocene } \\
\text { Moniwa, } \\
\text { Iwaine, } \\
\text { Tukimi-basi }\end{array}$ & $\mathrm{N} 32^{\circ} \mathrm{E}$ & $+40^{\circ}$ & $11^{\circ}$ & $59^{\circ} \mathrm{N}$ & $113^{\circ} \mathrm{W}$ & $8^{\circ} 13^{\circ}$ & 20 \\
\hline 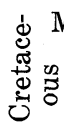 & $\begin{array}{l}\text { Middle or Lower } \\
\text { Cretaceous } \\
\text { Yamaguti pref. }\end{array}$ & $\mathrm{N} 58^{\circ} \mathrm{E}$ & $+50^{\circ}$ & $2^{\circ}$ & $42^{\circ} \mathrm{N}$ & $153^{\circ} \mathrm{W}$ & $2^{\circ} 3^{\circ}$ & 62 \\
\hline
\end{tabular}

By assuming now that direction of the geomagnetic dipole was approximately either parallel or anti-parallel with an axis of the earth, the pole of which had moved slowly over the earth's surface, the position of the pole of the wandering axis was estimated from the present data for four stages of Tertiary-Upper Pliocene, Lower Pliocene, Upper (or Middle) Miocene, and Lower Miocene-and for Middle or Lower Cretaceous. The results are summarized in Table III and in the figure, where an ellipse of confidence of $5 \%$ is also shown for each averaged position of the pole.

As is seen in the figure, the pole position is more apart from that of the present geographic pole as the geologic age is older. An approximate path of the polar wandering from the Cretaceous to the present may be traced from the data given in the present paper as illustrated with the thick solid line in the figure.

For the purpose of comparison, paths of the polar wandering, obtained hitherto from European,, ${ }^{5)}$ North American, ${ }^{6)}$ Indian, ${ }^{7)}$ and Australian data, ${ }^{8)}$ are also reproduced in the same figure. Comparing the curves of these paths with one another, it may be concluded that the tendency for the pole position to have been more apart 
from the present geographic pole in older geologic times holds in any case of the five paths, but no couple of them coincide with each other in their position, especially the discrepancy being great in their longitude.

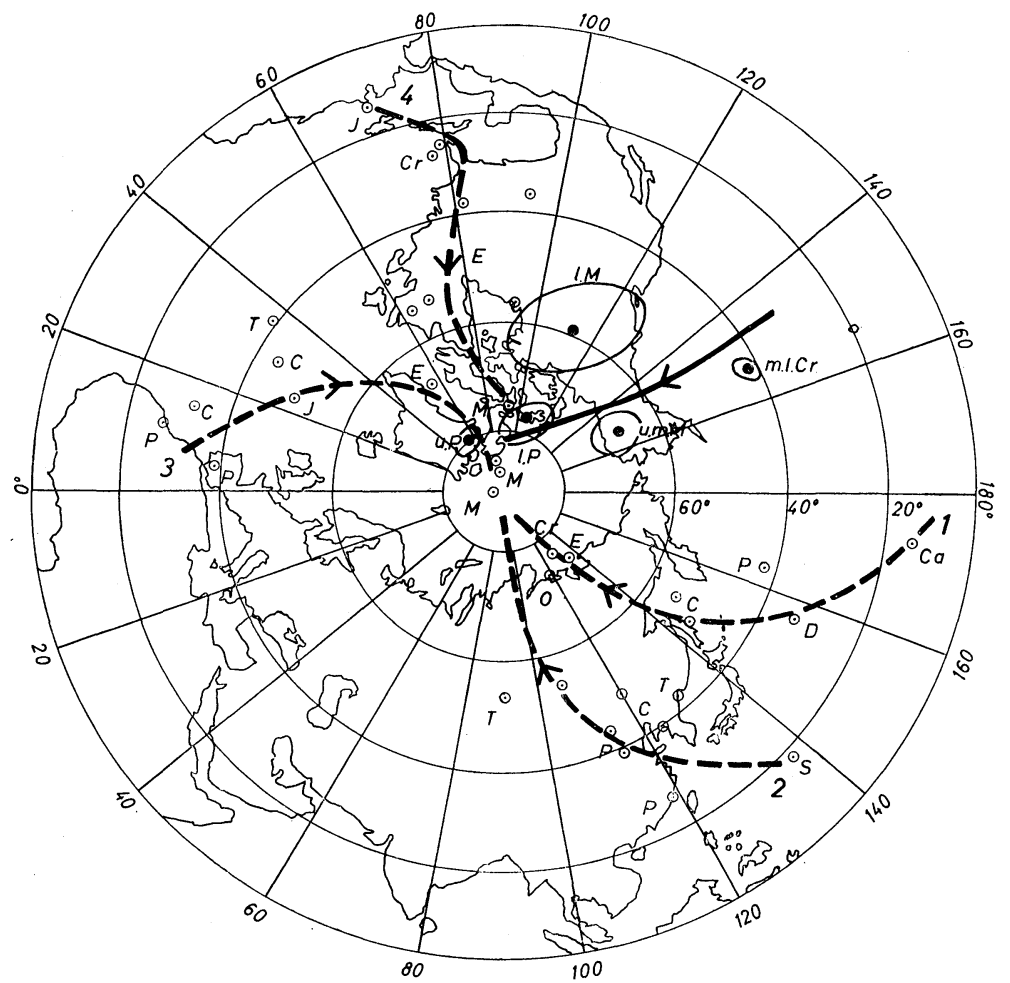

Ancient pole positions through geological age

$\longrightarrow$ Polar wandering path from Japanese data

$\begin{array}{lll}1--\rightarrow-- & , & \text { from European data } \\ 2--\rightarrow-- & ", & \text { from North American data } \\ 3--\rightarrow-- & , & \text { from Australian data } \\ 4--\rightarrow-- & , & \text { from Indian data }\end{array}$

P: Pliocene; u.P: Upper Pliocene; 1.P: Lower Pliocene; M: Miocene; u.m.M: Upper or Middle Miocene; 1.M: Lower Miocene; E: Eocene; O: Oligocene; Cr: Cretaceous; m.1.Cr: Middle or Lower Cretaceous; J: Jurassic; T: Triassic; P: Permian; C: Carboniferous; D: Devonian; S: Silurian; Ca: Cambrian

It is believed by the authors that the former half of what have been presented in this paper gives a support to the hypothesis of polar wandering of the earth, proposed by Runcorn. ${ }^{9)}$ The mutual discrepancy in the paths of polar wandering derived from the Japanese and foreign data might be attributed to continental drift, accompanied by rotation also, as was suggested by Blackett ${ }^{10)}$ and others. Further, it may be pointed out that the distance of the Miocene pole positions 
from the present geographic pole position, obtained from the Japanese data, is appreciably greater than that from the European or North American data. This result might suggest that a fairly large relative movement, probably rotation, of the Japanese Islands relative to the continents has taken place since the Miocene.

Rock-samples examined here are only those in Honsyû, Japan. It is desirable that this kind of research is extended over the Asiatic Continent, even for obtaining palaeomagnetic information in a limited area of the Far East or of the Western Pacific region.

\section{References}

1) T. Nagata, S. Akimoto, S. Uyeda, Y. Shimizu, M. Ozima, K. Kobayashi, and H. Kuno: Jour. Geomag. Geoelec., 9, 23 (1957).

2) K. Momose: Bull. Earthq. Res. Inst. (to be published).

3) R. A. Fisher: Proc. Roy. Soc., ser. A, 217, 295 (1953).

4) S. Akimoto and I. Kushiro: Jour. Geomag. Geoelec., 11 (to be published).

5) K. M. Creer, E. Irving, and S. K. Runcorn: Jour. Geomag. Geoelec., 6, 163 (1954).

6) E. Irving: Geofis. pura e appl. Milano, 33, 23 (1956).

7) J. A. Clegg, C. Radakrishnamurty, and P. W. Sahasrabudhe: Nature, 181, 830 (1958).

8) E. Irving and R. Green: Geophys. Jour. Roy. Ast. Soc., 1, 64 (1958).

9) S. K. Runcorn: Advances in Phys., 4, 244 (1955).

10) P. M. S. Blackett: Lectures on Rock Magnetism, Jerusalem, Weizmann Science Press (1956). 